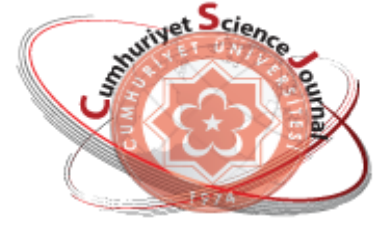

e-ISSN: $2587-246 X$

ISSN: $2587-2680$
Cumburiyet Science Journal

esy

Cumhuriyet Sci. J., Vol.38-4 (2017) 781-787

\title{
Investigation of Magnetic Field Response Features of Multilayer CoFe on Kapton Tape
}

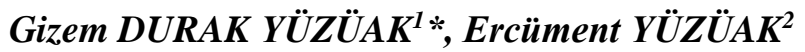 \\ ${ }^{1}$ Department of Engineering Physics, Faculty of Engineering, Ankara University, Beşevler, 06100 Ankara /TURKEY \\ ${ }^{2}$ Department of Material Science and Nanotechnology Engineering, Faculty of Engineering, Recep Tayyip Erdoğan \\ University, 53100 Rize /TURKEY
}

\begin{abstract}
Multilayer magneto-response cells (MMRC) fabricated on a non-magnetic layer among ferromagnetic $\left[\mathrm{Fe}_{65} \mathrm{Co}_{35}\right]_{5} / \mathrm{Cu} /\left[\mathrm{Fe}_{65} \mathrm{Co}_{35}\right]_{5}$ on a flexible substrate (Kapton tape) have been studied by using electron microscopy, X-ray diffraction, magnetic and magnetoimpedance measurements. In a similar cell, these layers have shown previously to have an outstanding magnetoimpedance (MI) effect performance when the selected growth substrate is a rigid one. Here, this MMRC produces on the Kapton tape and evaluate during the using as a magnetic field sensor and the magnetoimpedance characteristics are analyzed in terms of preparation conditions. For future sensing applications, this material is a promising candidate for giant magnetoimpedance effect with the range of low price and relatively high sensitivity features. In order to observe MI effect, the frequency dependence of impedance measurements has performed as a function of the applied low magnetic field. The impedance value of the cells has characterized by using constant $20 \mathrm{~mA} \mathrm{AC}$ current source at low frequencies ranges. Double (out of plane measurement) peak responses have obtained, showing MI ratios up to $\% 140$ and $\% 55$, their sensitivities are around $30 \% / \mathrm{Oe}$ and $17 \% / \mathrm{Oe}$ in the film on Si and Kapton tape, respectively.
\end{abstract}

Keywords: CoFe System, Magnetic Thin Film, Magnetic Field Response, Multilayer magneto-response cells.

\section{Çok Katmanlı Kapton Bant Üzerindeki CoFe'in Manyetik Alan Tepkili Özelliklerinin İncelenmesi}

Özet: Esnek bir alttaş (Kapton bant) üzerinde manyetik olmayan bir ara katman üzerinde üretilen ferromanyetik [Fe65Co35]5/Cu/[Fe65Co35]5 çok katmanlı manyeto-tepki hücreleri elektron mikroskobu, Xışını kırınımı, manyetik ve magneto empedans ölçümleri alınarak incelenmiştir. Benzer bir hücrede, bu katmanlar, seçilen büyüme altlığı sert bir yapıda olduğu zaman, olağanüstü bir magneto-empedans etki performansına sahip olduklarını göstermiştir. Burada, bu hücreler Kapton bant üzerinde büyütülerek, manyetik alan sensörü olarak kullanımı değerlendirilip ve magneto empedans özellikleri hazırlama koşulları açısından analiz edilmiştir. Gelecekteki algılama uygulamaları için bu malzeme, düşük fiyat aralığı ve nispeten yüksek hassasiyet özellikleri ile dev manyeto-empedans etkisi için umut verici bir adaydır. Manyeto empedans etkisini gözlemlemek için empedans ölçümlerinin frekans bağımlılığı, uygulanan düşük manyetik alanın bir fonksiyonu olarak gerçekleştirilmiştir. Hücrelerin empedans değeri, düşük frekans aralıklarında sabit $20 \mathrm{~mA}$ AC akım kaynağı ile karakterize edilmiştir. Si ve Kapton kaplamadaki filmde, duyarlılıkları, sırasıla, \% 30 / Oe ve\% 17 / Oe civarında olan, manyeto empedans oranlarını \% 140'a ve\% 55'e kadar gösteren pik tepkileri elde edilmiştir.

Anahtar Kelimeler: CoFe Sistemi, Manyetik İnce Film, Manyetik Alan Tepkisi, Çok Katmanlı Manyetik Tepki Hücreleri. 


\section{INTRODUCTION}

The giant magnetoimpedance effect materials and devices using these materials offer the next generation of sensor potential with cost-effective, flexible, highly sensitive features. Current and voltage sensors, ultra low magnetic field sensors, and particularly bio-sensors are frequently encountered in applications and can use in such high technology applications. Magnetic field sensors, which have arisen from the curiosity of creating a more specific sensor among scientists during the past 30 years, have become indispensable parts of today's commonly used in electric motors, dynamos and magnetic field detections. With the aid of these sensors, the momentary states of the motors are determined and muddled where necessary. In addition, these magnetic field sensors continue to develop rapidly in medical device applications used for the benefit of consumers in the world mass market and in advanced industrial products [1-5].

Especially in recent years, the production and use of these sensors have increased exponentially with the fundamentals of nanotechnological methods into the production of magnetic field sensors. Along with advances in nanotechnology, it is possible to change physical properties by reducing the dimensions of materials to nano-metric dimensions. Today, multifunctional metallic structures are being studied by many scientists with a growing interest. Metallic alloys obtained from nanostructures exhibit very different physical properties than volumetric alloys. Many physical quantities, such as magnetic, electrical, thermal and similar functional properties, have a critical prescription depending on the size of the nanoparticles. This change can be compared to volumetric alloys according to the size of the finite nanoparticles, the volume of intermediate sites or surface atoms. In particular, the effect of surface atoms on the physical properties of all materials is quite high. Before permanent magnets are produced in volumetric dimensions, it is often a scientific method to study in the form of nanoparticles and pass volumetric production in the direction of the resulting results. Thus, the effect of permanent nanostructures on the permanent magnet properties of the produced nano structures has been investigated. Examining the properties of nanoparticles of materials obtained with nanoparticles will play a key role in opening the future of applied technologies.

Magnetic sensors and their derivatives have an important place in the development and the progress of the modern world. Such sensors are repurposed almost in all industrial and engineering sectors, for example in magnetic thin film recording-decoding technology, coasting instruments, tracking systems and target detection, non-destructive testing methods, magnetic marking, labeling applications, magnetic and biomagnetic measurements and so on. Magnetic response sensors perform detection by converting the superiority of the existing magnetic field directly into an electrical signal. The sensitivity of the magnetic sensors within the application area determines the potential application potential. For example, the SQUID magnetometer can detect a magnetic field change with a gradient of $10^{-10}-10^{-}$ ${ }^{4}$ Oe. Due to its ability to detect such small magnetic field changes, it is used in brain mapping, magnetic anomaly detection and thin film applications (1-10 $\mathrm{nm})$ in very thin thicknesses. Other magnetic field sensors have lower sensitivity than SQUID. For example, induction, flux and giant magnetoresistive sensors can detect a magnetic field change in the order of $10^{-6}-10^{-2} \mathrm{Oe}$ [7]. Hall effect sensors can detect a magnetic field change in the range of $1-10^{6} \mathrm{Oe}$. Because of these features, these Hall sensors are suitable for contactless switching, magnetic memory reading and current measurement applications. In addition to the sensitivity requirement that affects the use of magnetic sensors in practical applications, production costs and power consumption also occupy an important place. Considering the cost of processing and power consumption, sensors made with thin films that exhibit a massive magnetoresistance effect 
are quite advantageous. However, such sensors have very small magnetic field sensitivity (1\% /Oe). Recently, a straightforward physical phenomenon which is called the magnetoimpedance is utilized under using of many of these areas. When a system assumed to be in this effect is subjected to a direct current (DC) magnetic field, very large changes in the impedance value can be observed. Among other GMI materials, multi-layer thin films are known most preferential responding matter with unique GMI effect for high-performance and highdurable sensing applications $[3,8]$.

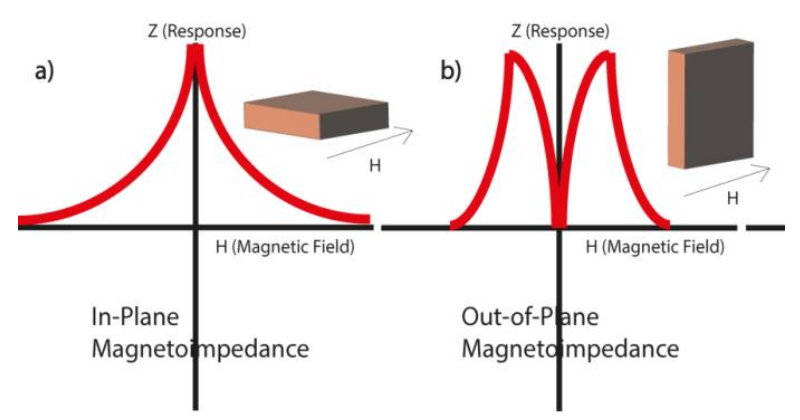

Figure 1.

(a) Illustration of GMI effect in applied magnetic field in the In-Plane direction.

(b) GMI effect in applied magnetic field in the Out-of-Plane direction.

Fundamentally, the magnetoimpedance effect is defined as the change of the impedance $(\mathrm{Z})$ of material with magnetic properties under applied dc magnetic field amplitude (Figure 1(a)-(b)). The magnetoimpedance effect is determined according to the direction of the magnetic field coming to the surface of the magnetic thin film. The change of this effect is given in detail in Figure 1(a)-(b). In addition, the magnetoimpedance value, which varies with the thickness of the magnetic thin film, has been formally mentioned. Total impedance variation based on the frequency of the alternating current in ferromagnetic materials. This is also the case, $Z=Z(f)$, where $f=\omega / 2 \pi$. An electric current flow through an indiscrete plain film the magnitude of magnetic field conceived by the electrical current will excite oscillations of magnetization. It means that the thin film impedance value depends not only on the conductivity $(\sigma)$ but also its magnetic permeability $(\mu)$. Magneto-impedance, GMI ratio, percentage changes with the performed static magnetic field is stated for:

$$
\Delta Z(\%)=100 \% \frac{Z(H)-Z\left(H_{\max }\right)}{Z\left(H_{\max }\right)}(1)
$$

where $\mathrm{Z}(\mathrm{H})$ and $\mathrm{Z}\left(\mathrm{H}_{\max }\right)$ represent the impedance in a magnetic field, $\mathrm{H}$, and maximum magnetic field, $\mathrm{H}_{\max }$ respectively. When evaluated from the application point of view, the highest field value that can be obtained with experimental equipment is $\mathrm{H}_{\max }$. This impression should be expanded by the electrodynamics Maxwell equations together with Landau-Lifshitz-Gilbert which is one of the most basic equations of magnetization dynamics when the magnetoimpedance effect is examined more deeply [9]. And the DC magnetic field sensitivity of a cell of GMI defined as follows:

$$
\eta=\frac{(\Delta Z / Z)_{\max }}{\Delta(H)}(2)
$$

where $\Delta \mathrm{H}$ is the magnetic field dependence of the full width at half maximum peak of GMI $(\%)[9$, 10]. The $H_{\max }$ value is the magnetic field value required to saturate the impedance value. This value is taken in practice as the greatest value of the system being measured [10].

In near-term publications, scientific studies on flexible electronics have begun to investigate the magneto-impedance effect on thin films grown by different authors and flexible substrates (Kapton), with an increasing interest in starting to work [11, 12]. When the studies on sensor applications are examined closely, it is observed that there is a clear increase in the technology that allows these applications to work under different conditions like non-rigid ones. When these conditions are closely conducted, it is thought that applications which are especially flexible and endurance are high value and technologically usable. For this 
reason, Co-Fe system considered in this study is grown on a flexible tape, which can operate under different conditions, and the physical properties of the magnified material are investigated.

\section{EXPERIMENTAL}

Multilayer thin film structures$\left[\mathrm{Fe}_{65} \mathrm{Co}_{35}\right]_{5} / \mathrm{Cu} /\left[\mathrm{Fe}_{65} \mathrm{Co}_{35}\right]_{5}$ cells were deposited by using magnetron sputtering system onto $\mathrm{Si}$ and Kapton tape in the vicinity of room temperature in order to investigate the elasticity features and the cell structure is sketched in Fig. 2. Elemental analysis was performed by electron microscopy before cell growth. For this experiment, a single layer Co-Fe system was grown on Si substrate and a compositional analysis was carried out. Accordingly, the composition of the thin film grown on $\mathrm{Si}$ with a thickness of $500 \mathrm{~nm}$ was found as $\mathrm{Fe}_{64.8} \mathrm{Co}_{35.2}$. Thin film composition obtained as a by-product of this work was found to be suitable for the multilayer thin films desired to be performed. The thickness of the Co-Fe layer used in the magnetoimpedance cell obtained by this study was determined to be $50 \mathrm{~nm}$ and the thickness of the $\mathrm{Cu}$ layer was set to $10 \mathrm{~nm}$. These identified layers repeated themselves 5 times. Thus, a total of $550 \mathrm{~nm}$ thick CoFe layer and 40 $\mathrm{nm} \mathrm{Cu}$ layer were grown on Kapton tape. The high purity commercially sputtering target was comprised $\mathrm{Fe}_{65} \mathrm{Co}_{35}$ (99.9\%) and $\mathrm{Cu}$ (99.99\%) circular disk. The working pressure was selected the 5 mTorr. In order to establish the essential smooth surface, the sputtering gun power used 80 Watt. The error margin in the stated impedance value was within $1.5 \%$. Magneto-impedance cells produced within the scope of this study have been developed using DC-RF sputtering system in Recep Tayyip Erdoğan University Central Laboratory. The magnetoimpedance cell was fabricated by growing as multilayer's cell on a glass substrate and Kapton tape with $2 \mathrm{~nm} \mathrm{Si}$ capping layer which is used for protecting the cell. Magneto-impedance measurements were performed for this produced cell.

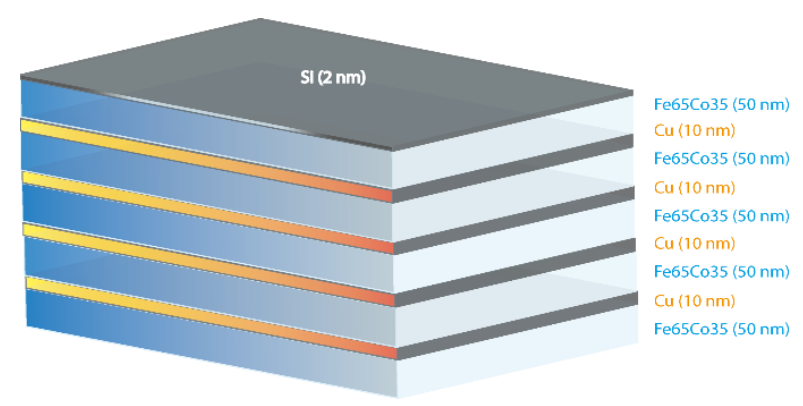

Figure 2. Illustration structure of GMI cell is produced within the scope of this study.

Via in-situ, the rate and thickness of film were conducted by a microbalance and via ex-situ by $\mathrm{X}$-ray reflectometry (XRR). Glancing incidence $\mathrm{X}$-ray diffraction (GIXRD) measurements and reflectometry trials were performed by Rigaku Smart Lab X-ray Diffractometer with the $\mathrm{CuK}_{\alpha}$ radiation at $1.54 \AA$ and the angle of $2^{\circ}$ selected as a glancing incidence in the diffractometer. The homogeneity and surface morphology measurements were done by Jeol Scanning Electron Microscope Spectroscopy. Magnetic properties of the films were measured by a Vibrating Sample Magnetometer (VSM) which both out-of-plane (OOP) and in-plane geometry (IP) of the applied magnetic. In order to get welldefined AC signal, AC current intensity is optimized from 2 to $20 \mathrm{~mA}$ and $20 \mathrm{~mA}$ was employed in a linear excitation.

\section{RESULT AND DISCUSSION}

The magneto-response material selected for this study is totally a $550 \mathrm{~nm}$ thick CoFe cell with a multilayer structure. Fig. 3 shows that the XRD patterns of the $\mathrm{CoFe}$ thin films on $\mathrm{Si}$ and Kapton tape and present a broad and singular hill, which reveals of the amorphous phase characteristic. As know, non-annealed (As-deposited) thin film reveals generally amorphous phase. Inset of Fig. 3 reveals that the surface of $\mathrm{CoFe}$ thin films on $\mathrm{Si}$ and Kapton tape have a SEM image. The both film surface images are so smooth and the inspected surface structure showing no large defects are also very uniform. 


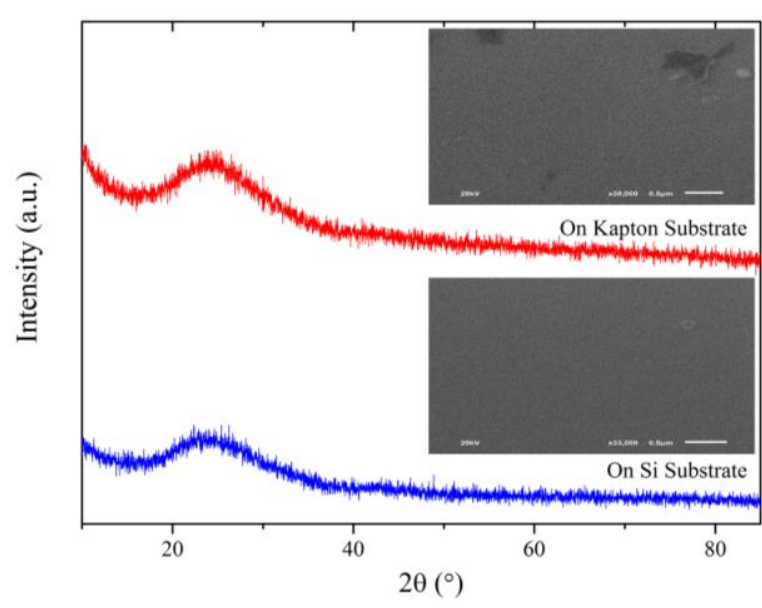

Figure 3. XRD patterns of $\left[\mathrm{Fe}_{65} \mathrm{Co}_{35}\right]_{5} / \mathrm{Cu} /\left[\mathrm{Fe}_{65} \mathrm{Co}_{35}\right]_{5}$ structure on $\mathrm{Si}$ and Kapton substrate. And inset of SEM micrographs of the same structures.

Fig. 4 presents the quasi-static magnetic measurement (hysteresis loop) in plane and outof-plane directions, obtained for $\left[\mathrm{Fe}_{65} \mathrm{Co}_{35}\right]_{5} / \mathrm{Cu} /\left[\mathrm{Fe}_{65} \mathrm{CO}_{35}\right]_{5}$ structure on Kapton tape. Here, results are removed from the diamagnetic contribution of the $\mathrm{Si}$ and Kapton substrate. The corresponding hysteresis loops for in plane and out of plane are shown the blue and red lines, respectively. It is important to note that the magnetic properties of the magnetization curves are not the same as those of the magnetic properties. Fig. 4 reveals that magnetic thin film shows the low coercivity both in plane and out-ofplane directions and also out-of-plane direction magnetization value is higher than in plane direction magnetization. Here, the change in magnetic behavior is verified in the plane and out of plane directions of cell. The main reason for such an effect to occur is the non-axial magnetic anisotropy that happens in the structure. When the magnetism measurement is performed in different magnetic orientations, the amount of orientation of the magnetic moments varies. If the amount of orientation was the same, no difference would be observed in the magnetization measurements. However, the magnitude of magnetization is very different from that of this measurement. As mentioned in the introductory part of this work, structures showing such magnetization values show a double peak magnetoimpedance effect. It is thought that this is one of the other important findings of this study. In addition, some parameters are shown in Table 1, which show the basic properties of the magnetization measurements. Particularly, challenging field values of the films are considerably low, and it is thought that these coercivity values are primarily due to the uniaxial anisotropy feature, which is due to the irregularities at the interfaces of the multilayer magnetic thin films. Such effect is also present in the literature [13].

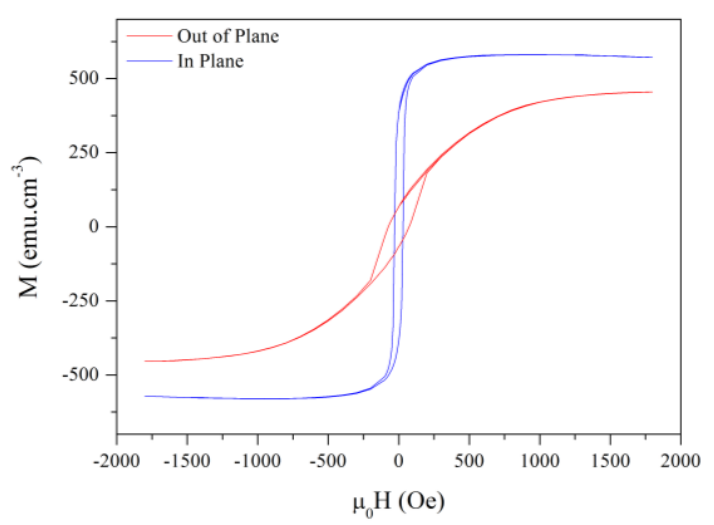

Figure 4. Magnetic field dependence of magnetization value in plane and out-of-plane directions of $\left[\mathrm{Fe}_{65} \mathrm{Co}_{35}\right]_{5} / \mathrm{Cu} /\left[\mathrm{Fe}_{65} \mathrm{Co}_{35}\right]_{5}$ structure on Kapton tape.

Table 1. Saturation magnetization $\left(\mathrm{M}_{\mathrm{s}}\right)$ values, Coercive field $\left(\mathrm{H}_{\mathrm{C}}\right)$ values, normalized remanent magnetization $\left(\mathrm{M}_{\mathrm{R}} / \mathrm{M}_{\mathrm{S}}\right)$ for the film on Kapton tape in plane and out of plane directions.

\begin{tabular}{llll}
\hline & $\mathrm{Ms}_{\mathrm{s}}$ & $\mathrm{H}_{\mathrm{C}}$ & $\mathrm{M}_{\mathrm{R}} / \mathrm{Ms}_{\mathrm{s}}$ \\
\hline In Plane value & $600 \mathrm{emu} \cdot \mathrm{cm}^{-3}$ & $45 \mathrm{Oe}$ & 0.87 \\
Out of Plane value & $420 \mathrm{emu}_{\mathrm{cm}} \mathrm{cm}^{-3}$ & $140 \mathrm{Oe}$ & 0.16 \\
\hline
\end{tabular}

As known, the in plane MI is substantially larger than that for the out of plane geometry due to the higher magnetic moment in plane. Therefore, this study also measured the magnetoimpedance measurements in plane. Magnetic field response of thin film has been studied as a function of applied magnetic field and frequency. Thus, magnetic field dependence of MI values of thin film on rigid substrate and flexible substrate are given in Fig. 5 (a) and (b), respectively. When the thin films obtained from this study are evaluated as a function of external applied frequency and external magnetic field, it is noticed that a critical frequency is separating the films according to the magnetic properties and a development in the 
form of magnetization curve indicating the existence of the magnetic field. The maximum frequency corresponding to the maximum variation of magneto-impedance $\mathrm{GMI}_{\max }$ was determined and given in inset of Figure 5 (a) and (b). In this study, the frequency-dependent maximum impedance value was determined at about $8 \mathrm{MHz}$ for magnetic thin film grown on $\mathrm{Si}$ and about $8 \mathrm{MHz}$ for magnetic thin film grown on Kapton tape. During this observation, the measurement of the magnetoimpedance effects was found for the values of 2, 8 and $10 \mathrm{MHz}$. According to these results, the increase of the frequency is faced with the result that the magneto-impedance value does not increase as a linear. When the consequences of this result were examined in the literature, no definite result was encountered. This should be clarified by the case that magnetic anisotropy in the flexible substrate might be enhanced by the grown dislocations or nano-cracking. Nevertheless, the conditions for making measurements at higher levels are needed.

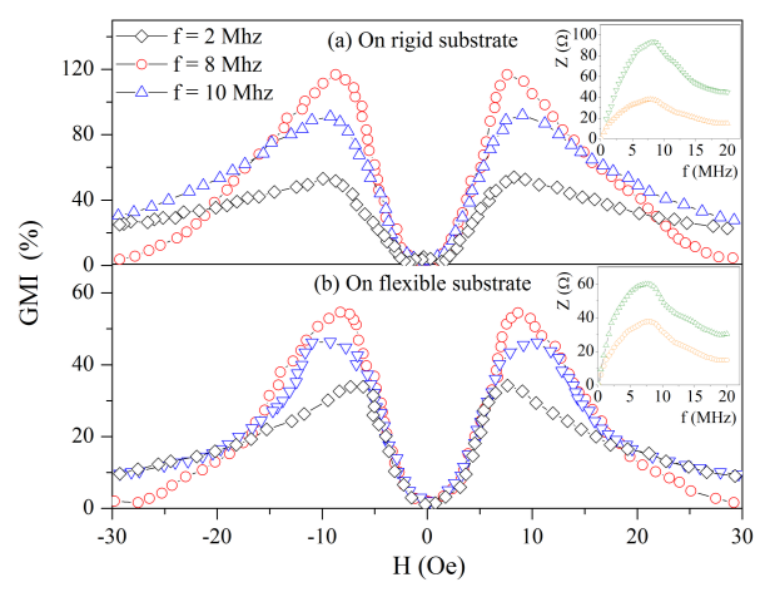

Figure 5. The out of plane giant magnetoimpedance ratio (GMI, \%) of thin films which are grown (a) on the rigid substrate and (b) on flexible substrate. Inset of frequency dependence of impedance values in applied and non applied magnetic fields.

Fig. 6 (a) and (b) shows that magnetic field dependence of sensitivity $(\eta)$ of GMI values, obtaining from multilayer cells on rigid and flexible substrate, respectively. Accordingly Fig. 6 (a), maximum $\eta$ value is attained about $30 \% / \mathrm{Oe}$ in applied frequency of $8 \mathrm{MHz}$. These findings are also compatible with the magnetoimpedance measurements made in this study and the literature. As seen in Fig. 6 (b), magnetoimpedance $\eta$ magnitudes found in thin films grown on flexible substrates are comparable to magnetic thin films grown on a rigid substrate. The magnitude of maximum $\eta$ is touched when compared with other GMI materials that are referred to main contribution to impedance change comes from skin depth. Since maximum $\eta$ value for the nanocrystalline $\left(\mathrm{Co}_{1-\mathrm{x}} \mathrm{Fe}_{\mathrm{x}}\right)_{89} \mathrm{Zr}_{7} \mathrm{~B}_{4}$ ribbons is about $8 \% / \mathrm{Oe}$, the value is greater than $105 \%$ in this study for the flexible one [14]. In addition, the magnetoimpedance magnitudes $(\mathrm{GMI}=300 \%)$ of the $\mathrm{Cu}$ layer placed between the two ferromagnetic layers (CoFeBSi) are still much greater than those obtained in this study [15].

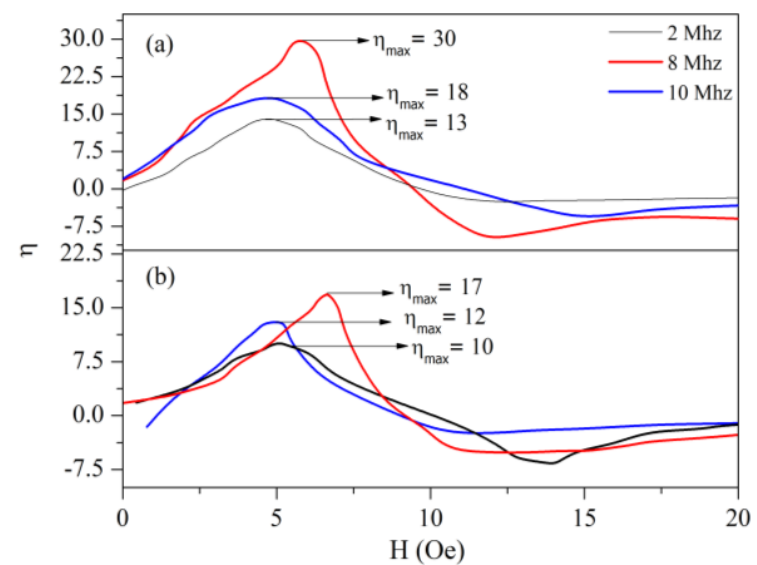

Figure 6. Out of plane giant magnetoimpedance sensitivity value in different magnetic fields $(2,8,10 \mathrm{MHz})$ of thin films which are grown (a) on the rigid substrate and (b) on flexible substrate.

\section{CONCLUSION}

In conclusion, multilayer magneto-response cells (MMRC) fabricated on a non-magnetic layer among ferromagnetic $[(\mathrm{Fe}-\mathrm{Co}) / \mathrm{Cu} /(\mathrm{Fe}-\mathrm{Co})] 5$ on Kapton tape have been evaluated by using electron microscopy, X-ray diffraction, magnetic and magnetic field dependence of impedance measurements. Even though the magnetoimpedance response of magnetic thin films grown on the Kapton tape is lower than the Si substrate, it is promising to develop a new generation of flexible electronic sensors that offer 
magnetoimpedance behavior that can be accepted by such multilayer magnetic thin films. When the results obtained from this study were examined, the following results were obtained.

- Thin films have been successfully grown on Kapton in multiple layers.

- Thin films grown on this flexible substrate can be used as appropriate magnetic field sensors at certain levels compared to thin films grown on $\mathrm{Si}$. Thin films grown on this flexible substrate show different sizes depending on the direction of the applied magnetic field. This is the evidence that the films are in anisotropic behavior.

- The magnetic thin films grown on the flexible substrate have been found to have properties that can be used to detect the magnetic field strength without being exposed to any annealing or thermal process.

\section{Acknowledgement}

This work was performed at Functional Materials Research Laboratory in Recep Tayyip Erdoğan University and partially supported by Research Fund of the Recep Tayyip Erdoğan University (Project Number: BAP 2014.109.06.02). Magnetic measurements are done at the Magnetic Materials Research Laboratory in Ankara University.

\section{REFERENCES}

[1]. Ripka P., "Sensors based on bulk soft magnetic materials: Advances and challenges," JMMM, 320, (2008) 2466-2473.

[2]. Tumanski S., Thin Film Magnetoresistive Sensors. Bristol, U.K.: IOP Publishing, 2001.

[3]. Zimmermann E., Verweerd A., Glaas W., Tillmann A., and KemnaA., "An AMR sensor-based measurement system for magnetoelectrical resistivity tomography" IEEE Sensors J., 5, (2005) 233-241.

[4]. Vopálenský M., Ripka P., and Platil A., "Precise magnetic sensors" Sens. Actuators A, 106, (2003) 38-42.

[5]. Freitas P.P., Ferreira R., Cardoso S., and Cardoso F., "Magnetoresistive sensors" J. Phys. Condens. Matter 19, (2007) 165221.
[6]. Prance R.J., Clark T.D., Prance H., "Ultra low noise induction magnetometer for variable temperature operation", Sens. Act., 85, (2000), 361-364.

[7]. V'azquez M., Advanced magnetic microwires. In: Handbook of Magnetism and Advanced Magnetic Materials, 1-34. John Wiley \& Sons, Ltd (2007).

[8]. Kraus L., Theory of giant magnetoimpedance in the planar conductor with uniaxial magnetic anisotropy. J. Magn. Magn. Mater. 195, (1999) 764.

[9]. Kraus L., The theoretical limits of giant magneto-impedance, J. Magn. Magn. Mater. 354, (1999) 167-196.

[10].Kurlyandskaya G.V., Bebenin N.G., Vas'kovskii V.O., Giant magnetic impedance of wires with a thin magnetic coating, Phys. Metal. Metallogr. 111 (2), (2011) 133-154.

[11].Agra K., Mori T.J.A., Dorneles L.S., Escobar V.M., Silva U.C., Chesman C., Bohn F., and Corrêa M.A., "Dynamic magnetic behavior in non-magnetostrictive multilayered films grown on glass and flexible substrates," J. Magn. Magn. Mater. 355, (2014) 136-141.

[12].Fernández E., Kurlyandskaya G.V., GarcíaArribas A., and Svalov A.V., "Nanostructured giant magneto-impedance multilayers deposited onto flexible substrates for low pressure sensing," Nanoscale Research Letters, 7, (2012) 230.

[13].Sharma P., and Gupta A., "Ion beam sputtered thin films of finemet alloy for soft magnetic applications" Nuclear Instruments and Methods in Physics Research Section B: Beam Interactions with Materials and Atoms, 244, (2006) 105-9.

[14].Chaturvedi A., Laurita N., Leary A., PhanM.H.,McHenryM.E., and SrikanthH., Giant magnetoimpedance and field sensitivity in amorphous and nanocrystalline $\left(\mathrm{Co}_{1-\mathrm{x}} \mathrm{Fe}_{\mathrm{x}}\right)_{89} \mathrm{Zr}_{7} \mathrm{~B}_{4}(\mathrm{x}=0,0.025,0.05,0.1)$ ribbons, Journal Of AppliedPhysics 109, (2011) 07B508.

[15].Panina L.V., Mohri K., Magneto-impedance in multilayerfilms, Sensors and Actuators 81, (2000) 71-77. 